\title{
Budidaya Jamur Tiram Putih (Pleurotus Ostreatus) Sebagai Percontohan Dan Unit Usaha Budidaya Jamur (Uubj) di Universitas Cenderawasih
}

\section{Cultivation of Oyster Mushroom As a Model and Profitable Unit at Cenderawasih University}

\author{
Verena Agustini), Supeni Sufaati, Bonifasia Elita Bharanti, Dirk Y.P. Runtuboi
}

Jurusan Biologi, FMIPA, Universitas Cenderawasih, *Email: verena.agustini@gmail.com

\begin{abstract}
Abstrak
Usaha jamur tiram putih (Pleurotus ostreatus) di Papua merupakan "bisnis baru" yang sangat menjanjikan. Unit Usaha Budidaya Jamur (UUBJ) yang merupakan implementasi program PPUPIK Jurusan Biologi FMIPA Universitas Cenderawasih (Uncen) telah merintis budidaya jamur tiram sejak tahun 2016. Jamur segar yang dihasilkan $15 \mathrm{~kg}$ per minggu dengan harga Rp. 70.000,-/kg. Selain sebagai profit, UUBJ juga menjadi sarana pembelajaran bisnis (wirausaha) bagi mahasiswa, alumni dan kelompok masyarakat. Solusi atau teknologi untuk menumbuhkan dan membentuk jiwa kewirausahaan adalah Entrepreunership Capacity Building (ECB) dan Participatory Action Learning System (PALS). Unit ini telah menghasilkan 5 orang entrepreuner baru di bidang usaha jamur tiram putih yang berasal dari mahasiswa dan alumni.
\end{abstract}

Kata kunci: Budidaya, Jamur tiram putih, Unit usaha, Jayapura

\begin{abstract}
Cultivation of Pleurotus ostreatus is a new business in Papua. This is a prospecting business. Mushroom Cultivation Unit (MCU) is an implementation of PPUPIK program in Biology Department, Faculty of Math and Sciences, Cenderawasih University. The program was established since 2016. This unit produces $15 \mathrm{~kg}$ of fresh oyster mushroom/week with the price of $R p$ 70.000,- $/ \mathrm{kg}$. Beside as a profitable unit, it is also plays as an entrepreneurship learning center for students, alumni, and communities. Techniques used in this program were Entreupreunership Capacity Building (ECB) and Participatory Action Learning System (PALS). So far, MCU has been produce 5 new entrepreneur in oyster mushroom cultivation business that come from both student and alumni.
\end{abstract}

Key words: cultivation, oyster mushroom, business unit, Uncen, Jayapura.

\section{PENDAHULUAN}

Budidaya jamur bukan merupakan hal yang baru bagi masyarakat Indonesia pada umumnya. Iklim negara kita yang panas dengan kelembaban yang cukup tinggi, merupakan kondisi yang ideal bagi tumbuhnya berbagai jenis jamur. Beberaja jenis jamur yang telah dikenal dan dibudidayakan secara luas di Indonesia antara lain jamur merang (Volvariela volvaceae), jamur kuping (Auricularia aricula), jamur shitake (Lentinula edodes) dan jamur tiram putih (Auricularia polytricha)(Susilawati \& Raharjo, 2010; Hariadi et al., 2013).

Salah satu aspek yang sangat menonjol adalah meningkatnya kesejahteraan masyarakat (Badan Pusat Statisik, 2013) dan salah satu indikatornya adalah perubahan pola konsumsi masyarakat dalam pemenuhan gizi dan pangan. Seperti 
kehidupan masyarakat yang sudah maju di daerah lain (Pulau Jawa dan Sumatera) pada umumnya, masyarakat di Papua mulai memperhatikan variasi dan mutu makanan jenis makanan. Pola tersebut berdampak pada permintaan terhadap jamur yang terus meningkat. Jamur menjadi salah satu pilihan yang banyak diminati selain berbagai jenis ikan laut.

Ketersediaan jamur dipasaran khususnya di Papua sangat terbatas yaitu hanya dijual di toko modern (swalayan). Kondisi ini menyebabkan harga jamur di Papua khususnya di Jayapura relatif lebih mahal, jika dibandingkan dengan harga jamur di daerah lain (pulau Jawa). Umumnya berbagai jenis jamur pangan yang dijual di Papua didatangkan dari luar Papua, yaitu dari Makassar atau Surabaya. Keterbatasan keterampilan dalam membudidayakan jamur menjadi salah satu penyebab terbatasnya persediaan stok jamur dipasar.

Di pihak lain, budidaya jamur relatif mudah dan murah, sebagai gambaran adalah budidaya jamur tiram putih. Selain bahan baku utama seperti media serbuk gergaji yang berlimpah, jamur termasuk tanaman yang tahan terhadap hama dan mudah beradaptasi dengan lingkungan. Jamur digolongkan sumber pangan organik bebas pestisida (Sutarman, 2012; Hariadi et al., 2013).

Unit Usaha Budidaya Jamur (UUBJ) tiram putih (Pleuretus ostreatus) Jurusan Biologi Universitas Cenderawasih (Uncen) berdiri pada tahun 2016. Pengenalan budidaya jamur kepada masyarakat pernah dilakukan melalui program Ipteks bagi Masyarakat (IbM) pada tahun sebelumnya, namun produksinya tidak menentu sehingga ketersediaan jamur tiram segar di Jayapura sering kosong. Peminat jamur tiram putih terus meningkat seiring dengan pola hidup sehat di Kota Jayapura. UUBJ tiram putih yang dikelola Jurusan Biologi Uncen ini selain bersifat profit, juga mengembangkan divisi yang bertugas dalam membina, membantu dan mendampingi mahasiswa dan alumni yang berkeinginan mulai berwirausaha yaitu dengan adanya inkubator bisnis jamur tiram dan turunannya. Tujuan didirikannya unit ini selain menghasilkan profit melalui produksi jamur segar, baglog, olahan jamur, pelatihan dan pendampingan wirausaha pemula baik mahasiswa, alumni maupun masyarakat sekitar kampus, serta tempat praktek kewirausahaan bagi mahasiswa.

\section{SOLUSI/TEKNOLOGI}

Dalam kegiatan ini alat dan bahan yang digunakan antara lain literatur usaha budidaya jamur tiram, peralatan isolasi jamur tiram. Benih awal jamur tiram putih (P. ostreatus) diperoleh dari CV. Volva Indonesia di Yogyakarta. Selain itu, diperlukan alat sterilisasi baik alat maupun sterilisasi media, baglog, dan tempat budidaya jamur tiram.

Teknik yang digunakan dalam menumbuhkan jiwa kewirausahaan dalam unit ini adalah Entrepreunership Capacity Building (ECB) untuk menginisiasi dan meningkatkan kemampuan kewirausahaan melalui pemberdayaan dan pendampingan. Metode lain, yakni Participatory Action Learning System (PALS) diterapkan guna meningkatan kapasitas entrepreneurship para mahasiswa maupun alumni yang memanfaatkan unit/inkubator yang ada di kampus Uncen.

\section{HASIL DAN DISKUSI}

Hasil survei harga jamur per Maret 2015 (survey awal proposal tahun 1) yang dilakukan oleh tim IbKIK Jurusan Biologi Uncen pada beberapa swalayan di Jayapura menunjukkan harga yang beragam, jauh lebih tinggi dibanding dengan daerah di luar Papua. Kondisi ini disebabkan karena ketersediaan jbeberapa bahan termasuk bibit jamur berasal didatangkan dari daerah lain dengan ongkos transportasi cukup mahal.

Tingginya harga komoditas jamur berpengaruh terhadap daya beli masyarakat, khususnya berpenghasilan rendah. Salah satu cara untuk menekan tingginya daya beli 
masyarakat antara lain adalah meningkatkan ketersediaan barang yang melimpah di pasaran. Ketersediaan barang yang banyak, dengan demikian mampu menurunkan harga di pasaran. Dengan demikian, diharapkan semua komponen masyarakat dapat menjangkau harga jual dipasaran.

Untuk meningkatkan ketersediaan jamur di pasaran, sangat tepat dengan membuat program produksi secara mandiri di Jayapura. Hal ini sesuai dengan program pemerintah daerah dalam jangka panjang. Upaya pemerintah dalam program percepatan pembangunan di wilayah Papua melalui kebijakan otonomi khusus (OTSUS) memberi dampak yang sangat signifikan terhadap dinamika kehidupan masyarakat baik, ekonomi, sosial, politik maupun budaya.

Hasil kegiatan ini sangat berpengaruh terhadap peningkatan informasi mengenai keberhasilan budidaya jamur tiram putih di Jayapura (Gambar 1). Keberadaan budidaya jamur tiram putih $(P$. ostreatus) memberikan harapan baru dalam suatu usaha produksi. Walaupun masih dalam kapasitas kecil, usaha budidaya jamur ini dapat dijadikan sebagai pilot project dalam pengembangan usaha budidaya jamur di Jayapura.

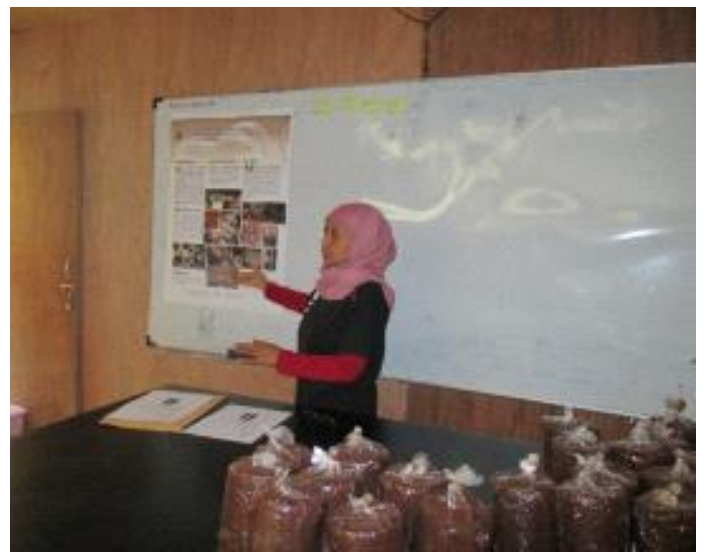

Gambar 1. Promosi pengembangan dan memperkenalkan produk jamur tiram di masyarakat.

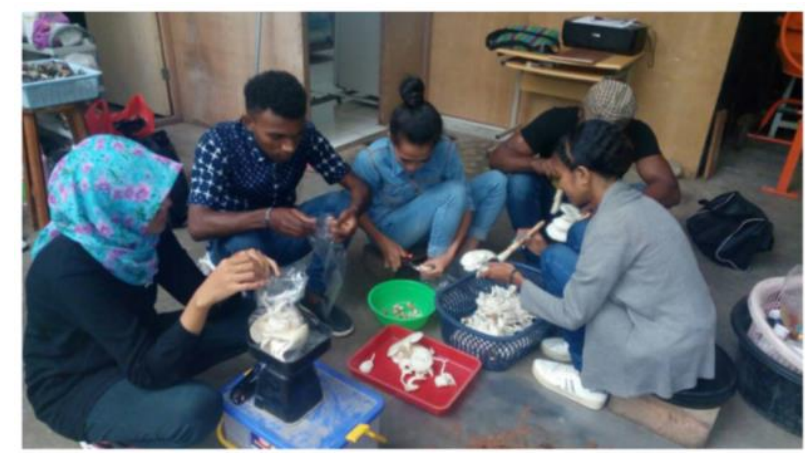

Gambar 2. Menumbuhkembangkan kewirausahaan melalui budidaya jamur tiram putih ( $P$. ostreatus) kepada mahasiswa.

Hasil pemasaran secara sederhana, mampu meningkatkan pendapatan yang cukup bagi pengembangan dan peningkatan kualitas produk yang dihasilkan (Gambar 2; Gambar 3). Hasil penjualan dengan produksi rata-rata $15 \mathrm{~kg}$ setiap minggu dijual dengan harga Rp. 70.000,-/kg sehingga diperoleh pendapatan $\mathrm{Rp} 1.050 .000$,- seminggu atau rata-rata Rp. 4.200.000,/bulan. Selain bersifat profit unit ini juga menjadi sarana pembelajaran berbisnis (kewirausahaan) bagi mahasiswa, alumni dan kelompok masyarakat yang ada di sekitar kampus Uncen. Tim UUBJ berfungsi sebagai motivator, inovator, fasilitator dan komunikator. Pendekatan program peningkatan kapasitas entrepreneurship adalah menggunakan metode PALS. Hasilnya dalam satu tahun terakhir telah dihasilkan 5 orang dari kalangan alumni dan mahasiswa yang mulai merintis usaha baru.

Pengembangan usaha budidaya jamur di Papua, khususnya di Jayapura sangat menjanjikan. Bahkan beberapa pengusaha kecil dan pengusaha muda siap mengembangkan budidaya jamur tiram. Beberapa diantaranya telah memesan baglog di UUBJ Uncen dalam jumlah yang besar. Permintaan jamur yang stabil di UUBJ Uncen menunjukkan bahwa pangsa pasar cukup tinggi. Hal ini menunjukkan bahwa jamur sangat diminati konsumen dan mempunyai prospek baik.

Berbagai produk hasil olahan yang berasal dari bahan baku jamur juga telah diperkenalkan. Diantaranya adalah sop 
jamur, bakso jamur, sate jamur, jamur krispi (Gambar 4), dan beberapa olahan masih dalam tahap uji kelayakan. Hasil ini sangat menarik bagi masyarakat karena sebelumnya, mereka mempunyai pengetahuan yang sangat terbatas dalam mengelola olahan jamur.

Pada kesempatan kegiatan ini, dilakukan sistem kelola keuangan yang transparan dan akuntabel serta bertanggung jawab, sistem dokumentasi dan pencatatan yang efektif dan efisien, dan adopsi serta modifikasi teknik budidaya jamur untuk optimalisasi produksi. Hal-hal tersebut merupakan bagian dari target dilakukannya kegiatan ini. Target lain yang dilakukan adalah tersedianya peralatan dan kelengkapan dalam budidaya $P$. ostreatus.

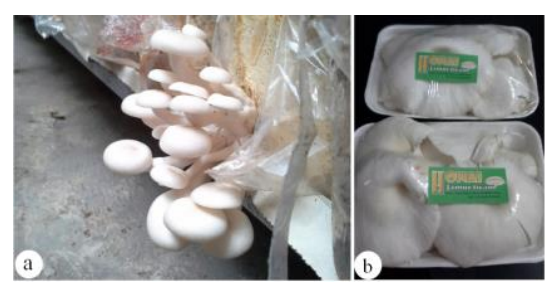

Gambar 3. Budidaya jamur tiram putih $(P$. ostreatus) (a), dan contoh pengepakan yang dilakukan oleh UUBJ Uncen (b).

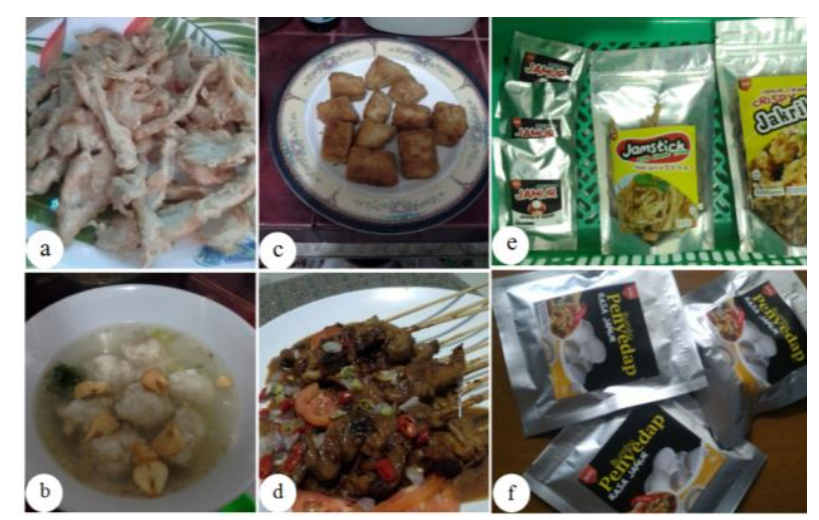

Gambar 4. Ragam produk olahan makanan dengan bahan baku jamur tiram putih.

Pengembangan UUBJ dapat dilakukan guna memenuhi kebutuhan sumber bibit berkualitas. Penyediaan bibit berkualitas merupakan salah satu usaha penting guna menjaga kualitas produk jamur tiram (Susilawati \& Raharjo, 2010;
Sutarman, 2012), termasuk kemungkinan pengembangan jamur tiram lokal yang tumbuh liar di Papua (Sufaati et al., 2017). Unit ini juga dapat mengembangkan budidaya jamur dari jenis lain, dengan melihat potensi di daerah (Erawati \& Tanjung, 2012). Apalagi, di daerah ini tersedia bahan baku media yang melimpah. Media sangat berpengaruh terhadap kandungan nutrisi jamur tiram (Shifriyah $e t$ al., 2012).

\section{KESIMPULAN}

Perintisan budidaya sebagai pilot project jamur tiram putih ( $P$. ostreatus) melalui UUBJ Uncen dapat dilakukan dengan baik. Program ini mampu mendorong minat wirausaha budidaya jamur, baik mahasiswa maupun masyarakat di Jayapura. Kegiatan ini mampu mendukung keberlangsungan dengan pendapatan yang cukup untuk melangsungkan aktivitas kegiatan budidaya.

\section{UCAPAN TERIMA KASIH}

Penulis menyampaikan terima kasih kepada Direktorat Riset dan Pengabdian Masyarakat (DRPM) yang telah memberikan dukungan dana kegiatan melalui hibah IbKIK tahun 2017 di Universitas Cenderawasih, Jayapura.

\section{PUSTAKA}

Badan Pusat Satatisk Propinsi Papua. 2013. Papua dalam angka.

Budi, M. 2011. Media tanam jamur tiram putih dengan variasi bahan dasar ampas sagu. Laporan Penelitian. Universitas Cenderawasih. Jayapura.

Erawati, D. dan R.H.R. Tanjung, 2012. Ekologi dan kandungan gizi jamur (Volvariela sp.) pada tandan kelapa sawit di kabupaten Kerom, Papua. Poster Seminar Nasional Mikologi. Purwokero, 15 - 16 Mei 2012.

Hariadi, N., L.Setyobudi, dan E. Nihayati. 2013. Studi pertumbuhan dan hasil 
produksi jamur tiram putih (Pleorotus ostreatus) pada media tumbuh jerami padi dan serbuk gergaji. Jurnal Produksi Pertanian. 1(1): 47-53.

Sarianti, T., H. Sasongko, dan A. Ratnawati. 2010. Aplikasi NPV at Risk dalam Analisis kelayakan finansial budidaya jamur tiram putih di Kabupaten Bogor Jawa Barat. Artikel Lepas. Di download, 17 Oktober 2014.

Shifriyah, A., K. Badami, dan S. Suryawati. 2012. Pertumbuhan dan produksi jamur tiram putih (Pleurotus ostreatus) pada penambahan dua sumber nutrisi. Agrovigor. 5(1): 8-13.

Striyanto, F. 2009. Jenis Jamur Tiram Putih. Jamursekolahdolan.blogspot.com, diakses pada bulan 21 Februari 2012.
Sufaati, S., V. Purnamasari, V. Agustini, dan Suharno. 2017. Tambir: Jamur alam Papua yang berpotensi sebagai jamur konsumsi. Jurnal Biologi Papua. 9(1): 20 - 24.

Susilawati dan B. Raharjo. 2010. Petunjuk teknis, budidaya jamur tiram (Pleourotus ostreatus var florida) yang ramah lingkungan (Materi Pelatihan Agribisnis bagi KMPH). Report No.50.STE.Final.BPTP Sumatera Selatan.

Sutarman. 2012. Keragaan dan produksi jamur tiram putih (Pleurotus Ostreatus) pada media serbuk gergaji dan ampas tebu bersuplemen dedak dan tepung jagung. Jurnal Penelitian Pertanian Terapan. 12(3): 163-168. 